\title{
Screening for brain metastases in patients with stage III non-small-cell lung cancer, magnetic resonance imaging or computed tomography?
}

Citation for published version (APA):

Schoenmaekers, J., Hofman, P., Bootsma, G., Westenend, M., de Booij, M., Schreurs, W., Houben, R., De Ruysscher, D., Dingemans, A-M., \& Hendriks, L. E. L. (2019). Screening for brain metastases in patients with stage III non-small-cell lung cancer, magnetic resonance imaging or computed tomography? A prospective study. European Journal of Cancer, 115, 88-96. https://doi.org/10.1016/j.ejca.2019.04.017

Document status and date:

Published: 01/07/2019

DOI:

10.1016/j.ejca.2019.04.017

Document Version:

Publisher's PDF, also known as Version of record

Document license:

Taverne

Please check the document version of this publication:

- A submitted manuscript is the version of the article upon submission and before peer-review. There can be important differences between the submitted version and the official published version of record.

People interested in the research are advised to contact the author for the final version of the publication, or visit the DOI to the publisher's website.

- The final author version and the galley proof are versions of the publication after peer review.

- The final published version features the final layout of the paper including the volume, issue and page numbers.

Link to publication

\footnotetext{
General rights rights.

- You may freely distribute the URL identifying the publication in the public portal. please follow below link for the End User Agreement:

www.umlib.nl/taverne-license

Take down policy

If you believe that this document breaches copyright please contact us at:

repository@maastrichtuniversity.nl

providing details and we will investigate your claim.
}

Copyright and moral rights for the publications made accessible in the public portal are retained by the authors and/or other copyright owners and it is a condition of accessing publications that users recognise and abide by the legal requirements associated with these

- Users may download and print one copy of any publication from the public portal for the purpose of private study or research.

- You may not further distribute the material or use it for any profit-making activity or commercial gain

If the publication is distributed under the terms of Article $25 \mathrm{fa}$ of the Dutch Copyright Act, indicated by the "Taverne" license above, 


\title{
Screening for brain metastases in patients with stage III non-small-cell lung cancer, magnetic resonance imaging or computed tomography? A prospective study
}

\author{
Janna Schoenmaekers ${ }^{a}$, Paul Hofman ${ }^{\mathrm{b}}$, Gerben Bootsma ${ }^{\mathrm{c}}$, \\ Marcel Westenend ${ }^{\mathrm{d}}$, Machiel de Booij ${ }^{\mathrm{e}}$, Wendy Schreurs ${ }^{\mathrm{f}}$, \\ Ruud Houben ${ }^{\mathrm{g}}$, Dirk De Ruysscher ${ }^{\mathrm{g}}$, Anne-Marie Dingemans ${ }^{\mathrm{a}}$, \\ Lizza E.L. Hendriks ${ }^{\text {a,* }}$
}

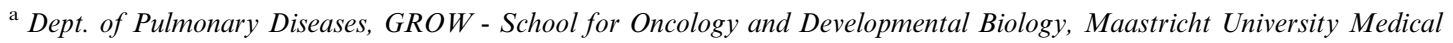
Center+, Maastricht, the Netherlands

${ }^{\mathrm{b}}$ Dept. of Radiology, Maastricht University Medical Center+, Maastricht, the Netherlands

${ }^{\mathrm{c}}$ Dept. of Pulmonary Diseases, Zuyderland Hospital Heerlen, Heerlen, the Netherlands

${ }^{\mathrm{d}}$ Dept. of Pulmonary Diseases, VieCuri Hospital, Venlo, the Netherlands

${ }^{\mathrm{e}}$ Dept. of Radiology, Zuyderland Hospital Heerlen, Heerlen, the Netherlands

${ }^{\mathrm{f}}$ Dept. of Nuclear Medicine, Zuyderland Hospital Heerlen, Heerlen, the Netherlands

${ }^{\mathrm{g}}$ Dept. of Radiation Oncology (MAASTRO), GROW - School for Oncology and Developmental Biology, Maastricht

University Medical Center+, Maastricht, the Netherlands
}

Received 13 December 2018; received in revised form 19 March 2019; accepted 5 April 2019

Available online 23 May 2019

\author{
KEYWORDS \\ NSCLC; \\ Screening; \\ Brain metastases; \\ Magnetic resonance \\ imaging; \\ Computed \\ tomography
}

\begin{abstract}
Introduction: Non-small-cell lung cancer (NSCLC) guidelines advise to screen stage III NSCLC patients for brain metastases (BMs), preferably by magnetic resonance imaging (MRI) or when contraindicated or not accessible a dedicated contrast enhanced -computed tomography (dCE-CT), which can be incorporated in the staging ${ }^{18}$ Fluodeoxoglucose-positron emission tomography $\left({ }^{18} \mathrm{FDG}-\mathrm{PET}-\mathrm{CE}-\mathrm{CT}\right)$. In daily practice, often a dCE-CT is performed instead of a MRI. The aim of the current study is to evaluate the additive value of MRI after dCE-CT, incorporated in the ${ }^{18}$ FDG-PET-CE-CT.

Patients and methods: It is an observational prospective multicentre study (NTR3628). Inclusion criteria included stage III NSCLC patients with a dCE-CT of the brain incorporated in the ${ }^{18}$ FDG-PET and an additional MRI of the brain. Primary end-point is percentage of patients with BM on MRI without suspect lesions on dCE-CT. Secondary end-points are
\end{abstract}

\footnotetext{
* Corresponding author: Dept. of Pulmonary Diseases, GROW-School for Oncology and Developmental Biology, Maastricht University Medical Center +, PO Box 5800, 6202 AZ, Maastricht, the Netherlands. Fax: +31(0)43-3871318.

E-mail address: lizza.hendriks@mumc.nl (L.E.L. Hendriks).
} 
percentage of patients with $\mathrm{BM}$ on dCE-CT and percentage of patients with $\mathrm{BM} \leq 1$ year of a negative staging MRI.

Results: Sixteen (7\%) patients with extracranial stage III had BM on dCE-CT and were excluded. One hundred forty-nine patients were enrolled. $7 / 149$ (4.7\%) had BM on MRI without suspect lesions on dCE-CT. One hundred eighteen patients had a follow-up of at least 1 year (four with BM on baseline MRI); eight of the remaining $114(7 \%)$ patients developed $\mathrm{BM} \leq 1$ year after a negative staging brain MRI.

Conclusion: Although in 7\% of otherwise stage III NSCLC patients, BMs were detected on staging dCE-CT, MRI brain detected BMs in an additional $4.7 \%$, which we consider clinically relevant. Within 1 year after a negative staging MRI, 7\% developed BM.

(c) 2019 Elsevier Ltd. All rights reserved.

\section{Introduction}

Brain metastases (BMs) frequently occur in non-smallcell lung cancer (NSCLC) patients, and risk increases with stage. About $20 \%$ of stage III NSCLC, patients have $\mathrm{BM}$ at baseline [1,2]. In all guidelines, it is advised to screen stage III NSCLC patients as usually only those without $\mathrm{BM}$ are eligible for intense combined modality treatment $[3-6]$. The preferred brain imaging modality is post contrast magnetic resonance imaging (MRI) or, when contra-indicated, a dedicated contrast enhanced-computed tomography (dCE-CT) [3-6]. However, access to MRI can be problematic, and there are also some contra-indications for MRI (e.g. some pacemakers, claustrophobia). In a United Kingdom (UK) survey (2014) on brain imaging in neurologically asymptomatic lung cancer patients, dCE-CT was preferred above MRI, presumably because of lack of access to MRI [7]. Another recently published European survey (462 responders) also showed that only $52.2 \%$ used MRI to screen for BMs. Moreover, only 63\% screened stage III NSCLC patients [8].

Furthermore, in all patients eligible for therapy with curative intent, a whole body ${ }^{18} \mathrm{~F}$-deoxyglucose-positron emission tomography $\left({ }^{18} \mathrm{FDG}-\mathrm{PET}\right)$ is advised to exclude distant metastases [3-5,9]. An ${ }^{18}$ FDG-PET is performed with a non-diagnostic low-dose CT (LD-CT) for attenuation correction, but a dCE-CT of the thorax, upper abdomen and brain can be added [10]. ${ }^{18}$ FDGPET with a LD-CT is not suitable for BMs detection [11-15]. From older studies (patient inclusions from 1980 up to 2004), including patients with mixed tumour types and tumour stages, it is known that MRI of the brain is more sensitive than $\mathrm{dCE}-\mathrm{CT}$ in detecting presence and especially number of metastases [16-20]. However, it has not been shown; this is still the case in the setting of screening for asymptomatic BMs in already ${ }^{18}$ FDG-PET staged stage III NSCLC patients. In recent years, the techniques concerning $\mathrm{CT}$ as well as MRI have improved. In a retrospective study $(\mathrm{N}=77)$ with these up-to date MRI and CT protocols (2008-2011), no additional BMs were found on MRI after ${ }^{18}$ FDG-PET-CT with dedicated brain CE-CT in stage III NSCLC patients. In contrast, $16 \%$ of those with only a LD-CT were diagnosed with BM on MRI [15]. BM remain a serious issue as in this retrospective study, $13 \%$ with a negative staging brain MRI developed symptomatic BM within a year of NSCLC diagnosis [15]. A similar percentage of BM development was found in another large retrospective series $(\mathrm{N}=838)$ of stage III NSCLC patients that underwent baseline brain imaging [21]. When dCE-CT of the brain performed in the same setting as ${ }^{18}$ FDG-PET-CT could lead to the same yield of BM detection as ${ }^{18}$ FDG-PET-LD-CT with a separate brain MRI, a substantial gain in time and resources could be expected. In this prospective observational multicentre study, we evaluated whether there is a clinically relevant additive value of MRI to dedicated brain CE-CT (performed as part of the ${ }^{18} \mathrm{FDG}$ PET-CE-CT) in detecting asymptomatic BM in stage III NSCLC patients when both are performed in standard work-up.

\section{Materials and methods}

\subsection{Study design and patient selection}

This was a prospective, multicentre $(\mathrm{N}=3)$ study in the Netherlands. In the participating hospitals, it is routine practice to perform a dCE-CT of the brain and chest together with the ${ }^{18}$ FDG-PET-CT, when no recent diagnostic chest CE-CT is available. In addition, standard practice is to perform brain MRI in all stage III NSCLC patients eligible for therapy with curative intent. Patients were included by prospectively screening the agenda of the weekly multidisciplinary lung tumour boards of the participating hospitals. As according to Dutch guidelines, all lung cancer patients must be discussed in these tumour boards, no patients are missed. All stage III (7th tumour-node-metastasis [TNM] 
edition) NSCLC patients scheduled for treatment with curative intent were included. For inclusion in this study, stage III was based on ${ }^{18}$ FDG-PET-CE-CT with $\mathrm{dCE}-\mathrm{CT}$ of the brain, i.e. without taking into account the results of MRI.

In addition, the number of patients with asymptomatic BM found on ${ }^{18}$ FDG-PET-CE-CT in otherwise stage III NSCLC was scored. The exclusion criteria included a second primary cancer within 2 years of stage III NSCLC diagnosis (except recurring NSCLC eligible for treatment with curative intent, cervical cancer in situ or non-melanoma skin cancer), no dCE-CT of the brain during the ${ }^{18}$ FDG-PET scan and no brain MRI and mixed histology (i.e. SCLC and NSCLC). Initially, the aim was also to exclude patients with a brain MRI performed more than 3 weeks after the ${ }^{18}$ FDG-PET-CE$\mathrm{CT}$ as it could not be excluded that BM not visible on dCE-CT of the brain became visible on MRI in a longer time period. However, during the study, it proved to be very difficult to obtain the MRI within this time, so all patients fulfilling the other criteria were included, irrespective of MRI timing.

The MUMC+ethics committee stated that patient informed consent was not mandatory according to the Dutch law 'Medical Research (human subjects) Act' as both ${ }^{18}$ FDG-PET-CE-CT and MRI are standard workup according to the Dutch NSCLC guideline, and work-up and treatment were not influenced by the study (METC 12-4-126). The study was registered on the Dutch Trial Registry (NTR3628). Because of the observational study design, patients who already had had a CE-CT of the chest did not undergo a CE-CT combined with the ${ }^{18}$ FDG-PET scan, as standard practice was to perform only a LD-CT combined with the ${ }^{18}$ FDG-PET scan. If not already performed, brain MRIs were advised during the tumour boards, but the decision to perform a brain MRI was according to the treating physician.

\subsection{Outcomes}

Primary end-point was the percentage of patients with stage III NSCLC (based on ${ }^{18}$ FDG-PET-CE-CT) diagnosed with BMs on MRI, but without suspect lesions on the dCE-CT of the brain. Secondary end-points were as follows: (1) the percentage of patients in which asymptomatic BM were found on ${ }^{18}$ FDG-PET-CE-CT and (2) the percentage of patients developing symptomatic BM within 1 year after a negative brain MRI.

The following data were collected: age; gender; World Health Organisation performance score; smoking status; date of stage III NSCLC diagnosis; date of ${ }^{18}$ FDG-PET-CE-CT and brain MRI; histology; whether molecular testing was performed; TNM; details on therapy modality (chemotherapy cycles, delivered radiation dose and whether treatment was completed) and development of BM during follow-up (date, number, treatment modality).

\subsection{MRI and dCE-CT of the brain protocols (during ${ }^{18} F D G-P E T-C E-C T$ )}

See supplemental data S1.

\subsection{Statistical analyses}

\subsubsection{Sample size calculation}

The primary end-point for this study was the percentage of patients diagnosed with BMs on MRI, but without suspect lesions on the dCE-CT of the brain. After intercollegial discussion, difference of more than $2 \%$ was considered clinically relevant. With an expected difference of $2 \%$ and a one-sided $95 \%$ confidence interval (95\% CI) not exceeding $4 \%$, a total of $118{ }^{18}$ FDG-PETCE-CT and brain MRI staged patients were needed to calculate a one-sided $95 \%$ CI around $2 \%$ that excluded the $4 \%$ threshold, given these assumptions. After 118 patients were included, we decided to continue including patients during the 1 year follow-up period of the first 118 patients to have more solid data for the primary end-point.

Statistical analysis was performed with SPSS (version 23; SPSS Inc., Chicago, IL). The secondary end-points and baseline characteristics were analysed using standard descriptive statistics.

\section{Results}

All NSCLC patients presented at the tumour boards from December 2012 until October 2017 were screened for eligibility. Three hundred thirty-eight consecutive patients had extracranial stage III NSCLC based on ${ }^{18}$ FDG-PET. In $118 / 338$ patients $(35 \%)$, no dedicated brain CE-CT was performed together with the staging FDG-PET, 62 out of these $118(52 \%)$ patients had only a LD-CT for attenuation correction, and after central revision of the CE-CTs of the brain, 56/118 (47\%) had a CE-CT but without dedicated brain imaging protocol (i.e. wrong field of view and/or hands above the head). Seventy-one $(32 \%)$ of the remaining 220 patients were excluded because of asymptomatic BMs on dCE-CT of the brain $(N=16,7 \%)$, second primary $(N=11,5 \%)$ or no brain MRI $(N=44,20 \%)$. As a result, 149 patients were included, of whom 118 had a follow-up of at least 1 year (Fig. 1). Baseline characteristics are summarised in Table 1.

Median time (range) between ${ }^{18}$ FDG-PET-CE-CT and MRI was $2.4(0.0-8.1)$ weeks. In $24.7 \%$, time from ${ }^{18}$ FDG-PET to MRI was more than 3 weeks.

In $7 / 149(4.7 \%)$ patients, BMs were detected on MRI despite no suspect brain lesions on dCE-CT. In retrospect, after central review of all the imaging, in one of these seven patients, a solitary BM could be identified 


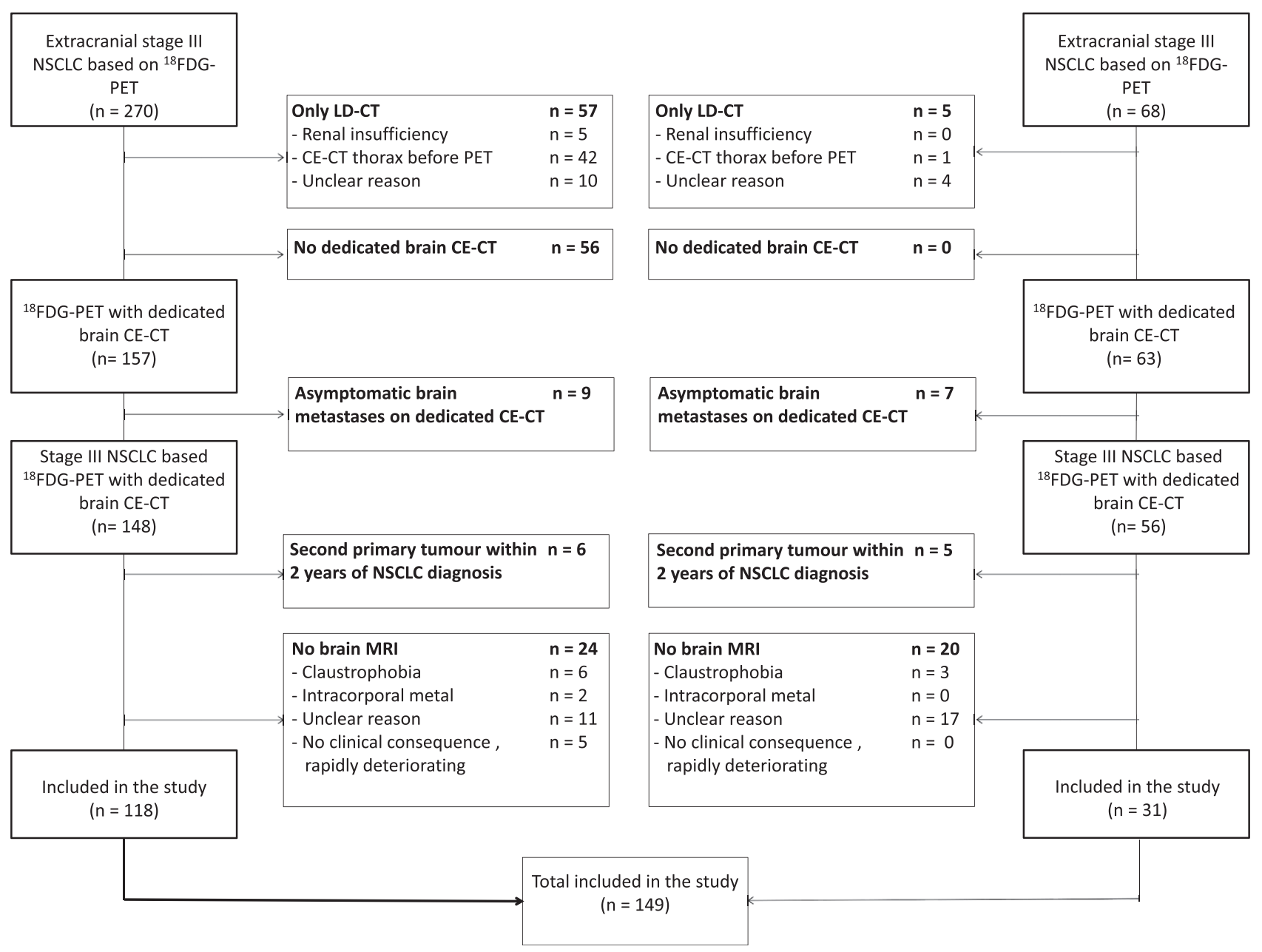

Fig. 1. Consort diagram. CE-CT, contrast enhanced-computer tomography; MRI, magnetic resonance imaging; NSCLC, non-small-cell lung cancer; ${ }^{18}$ FDG-PET, ${ }^{18}$ F-deoxyglucose-positron emission tomography; LD-CT, low-dose CT.

on the ${ }^{18}$ FDG-PET-CE-CT. Characteristics of these seven patients are summarised in Table 2.

118/149 patients had a follow-up period of at least 1year. Treatment characteristics of these 118 patients are in Table 3. 4/118 had already baseline BMs on MRI $(3.4 \%)$.

8/114 (7\%) patients developed symptomatic BM within a year of a negative staging brain MRI. All but one of these patients completed the treatment for their stage III disease (six concurrent chemoradiation, one radical radiotherapy only). Characteristics of these eight patients are summarised in Table 4.

\section{Discussion}

In this prospective observational multicentre study, with up-to-date staging and imaging protocols, we evaluated whether brain MRI was superior to ${ }^{18}$ FDG-PET-CECT with dCE-CT of the brain in detecting asymptomatic BM in otherwise stage III NSCLC patients. We defined a difference of more than $2 \%$ clinically relevant, as after multidisciplinary discussion, we felt that missing a higher percentage of $\mathrm{BM}$ would not be desirable as a $\mathrm{BM}$ diagnosis changes the treatment plan (i.e. either radically treat the $\mathrm{BM}$ or when not possible withhold patients from an intense multimodality treatment). In our study, brain MRI was superior to dCE-CT of the brain as an additional $4.7 \%$ of patients were diagnosed with BM on MRI. This study also shows that adequate brain imaging is necessary in this patient population, as despite the finding that 16 patients $(7 \%)$ were diagnosed with asymptomatic BM on dCE-CT of the brain, brain MRI detects BM in an additional $4.7 \%$. The total percentage of asymptomatic BM detected is comparable to previous studies $[1,15]$.

In the participating hospitals, performing a MRI brain within a reasonable time period after ${ }^{18}$ FDG-PET proved to be difficult, as in $24.7 \%$ the time from ${ }^{18}$ FDGPET to MRI was more than 3 weeks. This is not a problem unique for the participating hospitals, as in a United Kingdom survey (2014), CE-CT was preferred above MRI, presumably because of lack of access to MRI [7]. However, delay from ${ }^{18}$ FDG-PET-CE-CT to MRI with subsequent growth of a microscopic BM does 
Table 1

Baseline characteristics.

\begin{tabular}{|c|c|c|c|}
\hline \multirow[t]{2}{*}{ Patient characteristic } & \multirow{2}{*}{$\frac{\text { Group } 1}{(\mathrm{~N}=118)}$} & \multirow{2}{*}{$\frac{\text { Group } 2}{(\mathrm{~N}=31)}$} & \multirow{2}{*}{$\frac{\text { Total }}{(\mathrm{N}=149)}$} \\
\hline & & & \\
\hline Median age (years) & 68 & 62 & 68 \\
\hline \multicolumn{4}{|l|}{ WHO PS, N (\%) } \\
\hline 0 & $38(32.2)$ & $14(45.2)$ & $52(34.9)$ \\
\hline 1 & $60(50.8)$ & $13(42)$ & $73(49)$ \\
\hline 2 & $14(11.9)$ & $3(9.7)$ & $17(11.4)$ \\
\hline 3 & $2(2)$ & $1(3.2)$ & $3(2)$ \\
\hline 4 & $0(0)$ & $0(0)$ & $0(0)$ \\
\hline Unknown & $4(3.4)$ & $0(0)$ & $4(2.7)$ \\
\hline \multicolumn{4}{|l|}{ Smoking status, N (\%) } \\
\hline Current & $60(50.8)$ & $17(54.8)$ & 77 (51.7) \\
\hline Former & $54(45.8)$ & $12(38.7)$ & $66(44.3)$ \\
\hline Never & $2(1.7)$ & $1(3.2)$ & $3(2)$ \\
\hline Unknown & $2(1.7)$ & $1(3.2)$ & $3(2)$ \\
\hline \multicolumn{4}{|l|}{ cTstage, N (\%) } \\
\hline $\mathrm{o} / \mathrm{x}$ & $3(2.5)$ & $2(6.5)$ & $5(3.4)$ \\
\hline $1 \mathrm{a}$ & $4(3.4)$ & $1(3.2)$ & $5(3.4)$ \\
\hline $1 b$ & $8(6.8)$ & $1(3.2)$ & $9(6)$ \\
\hline $2 \mathrm{a}$ & $24(20.3)$ & $1(3.2)$ & $25(16.8)$ \\
\hline $2 b$ & $12(10.2)$ & $1(3.2)$ & $13(8.7)$ \\
\hline 3 & $19(16.1)$ & $4(12.9)$ & $23(15.4)$ \\
\hline 4 & $48(40.7)$ & $21(67.7)$ & $69(46.3)$ \\
\hline \multicolumn{4}{|l|}{ cNstage, N(\%) } \\
\hline $\mathrm{o} / \mathrm{x}$ & $12(10.2)$ & $9(29)$ & $21(14.1)$ \\
\hline 1 & $5(4.2)$ & $3(9.7)$ & $8(5.4)$ \\
\hline 2 & $72(61)$ & $15(48.4)$ & $87(58.4)$ \\
\hline 3 & $29(24.6)$ & $4(13)$ & $33(22.1)$ \\
\hline \multicolumn{4}{|l|}{ cTNM (7th edition) } \\
\hline IIIA & $62(52.5)$ & $16(51.6)$ & $78(52.3)$ \\
\hline IIIB & $52(44.1)$ & $12(38.7)$ & $64(43)$ \\
\hline $\begin{array}{l}\text { IV (brain metastases diagnosed } \\
\text { on baseline brain MRI) }\end{array}$ & $4(3.4)$ & $3(9.7)$ & $7(4.7)$ \\
\hline \multicolumn{4}{|l|}{ Histology, N (\%) } \\
\hline Adenocarcinoma & $56(47.5)$ & $11(35.5)$ & $67(45)$ \\
\hline Squamous cell carcinoma & $46(39)$ & $11(35.5)$ & $57(38.3)$ \\
\hline Large cell carcinoma & $1(0.8)$ & $3(9.7)$ & $4(2.7)$ \\
\hline NOS & $13(11)$ & $6(19.4)$ & $19(12.8)$ \\
\hline LCNEC & $2(1.7)$ & $0(0)$ & $2(1.3)$ \\
\hline \multicolumn{4}{|l|}{ Molecular analysis, N (\%) } \\
\hline Not performed & $62(52.5)$ & $23(74.2)$ & $85(57)$ \\
\hline \multicolumn{4}{|l|}{ Performed $^{\mathrm{a}}$} \\
\hline$E G F R / K R A S$ wt, $A L K-$ & $28(50)$ & $5(62.5)$ & $33(51.6)$ \\
\hline EGFR mutation & $1(1.8)$ & $0(0)$ & $1(1.6)$ \\
\hline$K R A S$ mutation & $25(44.6)$ & $3(37.5)$ & $28(43.8)$ \\
\hline$A L K$ translocation & $1(1.8)$ & $0(0)$ & $1(1.6)$ \\
\hline Other & $1(1.8)$ & 0 & $1(1.6)$ \\
\hline
\end{tabular}

N, number; WHO PS, World Health Organisation Performance status; $\mathrm{T}$, tumour; N, node; MRI, magnetic resonance imaging; NOS, not otherwise specified; LCNEC, large cell neuroendocrine carcinoma; EGFR, epidermal growth factor receptor; KRAS, Kirsten Rat Sarcoma viral antigen; ALK, anaplastic lymphoma kinase; wt: wildtype. Group 1: first cohort of included patients with year of follow up; Group 2: additional cohort of included patients during the year follow up of first group.

${ }^{a}$ Percentage computed only for those with known molecular analysis.

not seem to be the explanation for the lesions found on MRI for the seven patients in the present study, as median time (range) to MRI was 2.7 (0.4-6.4) weeks.

MRI can cause a delay in the workup of stage III NSCLC which is not desirable as, for example, according to the Dutch SONCOS document (SONCOS: 'Foundation for Oncological Collaboration') treatment has to start within 5 weeks of diagnosis [22]. Our results stress the importance of adequate screening for BM in this patient population and that a brain MRI is necessary, even after a dCE-CT of the brain (which can, as in our trial, be incorporated in the ${ }^{18} \mathrm{FDG}$-PET or can be performed after a ${ }^{18}$ FDG-PET). Screening with MRI should be more accessible and better integrated in the standard work-up as for example in the UK and European surveys, not all physicians screened their stage III patients and not all use MRI [7,8]. Even in our prospective study, in which MRIs, if not already performed, were advised during the tumour boards, not all patients without contraindications underwent MRI of the brain. In this observational study, no real-time check was performed to evaluate whether this advice was followed.

Detecting BM in this patient population is important as combined modality treatment is intense with a high incidence of adverse events $[23,24]$. Despite this intense treatment, the 5-year overall survival is only around $30 \%$ in recent series [25-27]. Most patients diagnosed with BM will not be eligible for this intensive treatment regimen, and some will be diagnosed with single or oligo-BM, potentially amenable to treatment with curative intent (surgery or radical radiotherapy) [28]. Our findings in stage III NSCLC also reinforce the recommendations recently published in the European Respiratory Journal to screen for BM in this patient population, and we show that MRI is more sensitive than dCE-CT $[29,30]$. The National Institute for health and care excellence in the UK recently updated their brain imaging advise, and MRI is now explicitly advised in the staging work-up of stage III NSCLC [6].

Another important issue is that $7.5-15 \%$ of stage III NSCLC patients with negative baseline brain imaging will develop (mostly symptomatic) BM within a year of NSCLC diagnosis [15,31]. With longer follow-up, this percentage increases further: in the NVALT-11/ DLCRG-02 trial for example, which mandated baseline brain imaging with MRI or CT, $27.2 \%$ of patients developed symptomatic BM within 2 years after treatment with radical intent [32]. It is not known whether these metastases were already present at initial stage III diagnosis and were not detected by brain imaging or that these were newly developing metastases. Maybe some could have been detected with more sensitive MRI-techniques (higher contrast dose or higher Tesla), but this can also increase the possibility for false positive findings [33,34].

Regular follow-up brain imaging in high-risk patients is also an option to detect BMs when they are possibly still eligible for therapy with radical intent, but this is not recommended in NSCLC guidelines [3-5,9]. Known risk factors (adenocarcinoma, higher nodal stage and female gender) alone cannot predict reliably enough 
Table 2

Patient characteristics of seven patients with BMs on MRI despite no suspect lesions on dCE-CT of the brain.

\begin{tabular}{|c|c|c|c|c|c|c|c|}
\hline $\begin{array}{l}\text { Patient } \\
\text { characteristic }\end{array}$ & Patient 1 & Patient 2 & Patient 3 & Patient 4 & Patient 5 & Patient 6 & Patient 7 \\
\hline Gender (M/F) & $\mathrm{F}$ & M & $\mathrm{M}$ & $\mathrm{M}$ & $\mathrm{M}$ & $\mathrm{M}$ & $\mathrm{F}$ \\
\hline Age (years) & 60 & 62 & 65 & 48 & 67 & 65 & 62 \\
\hline WHO PS score & 0 & 1 & 1 & 1 & 1 & 0 & 0 \\
\hline cTstage & 4 & $1 b$ & 3 & 3 & $2 \mathrm{a}$ & 3 & 4 \\
\hline cNstage & 3 & 2 & 1 & 2 & 2 & 2 & 2 \\
\hline Histology & Adeno & Adeno & Squamous & Squamous & Adeno & Squamous & Adeno \\
\hline $\begin{array}{l}\text { Molecular } \\
\text { analysis }\end{array}$ & None & KRAS & Not performed & None & None & Not performed & None \\
\hline $\begin{array}{l}\text { Time between } \\
\text { dCE-CT } \\
\text { and MRI } \\
\text { (weeks) }\end{array}$ & 1.86 & 6.43 & 0.43 & 1.29 & 5.86 & 2.29 & 1.00 \\
\hline $\begin{array}{l}\text { Thoracic } \\
\text { treatment }\end{array}$ & $\begin{array}{l}\text { Chemotherapy } \\
\text { (cisplatin/ } \\
\text { pemetrexed) }\end{array}$ & $\begin{array}{l}\text { Chemotherapy } \\
\text { (Carboplatin/ } \\
\text { pemetrexed) }\end{array}$ & $\begin{array}{l}\text { Neoadjuvant CRT } \\
\text { (cisplatin/etoposide) } \\
+ \text { Lobectomy }\end{array}$ & $\begin{array}{l}\text { Sequential CRT } \\
\text { (gemcitabin/ } \\
\text { cisplatin) }\end{array}$ & $\begin{array}{l}\text { Sequential CRT, } \\
\text { after } 1 \text { cycle } \\
\text { progressive disease }\end{array}$ & $\begin{array}{l}\text { Concurrent CRT } \\
\text { (Cisplatin/ } \\
\text { etoposide) }\end{array}$ & $\begin{array}{l}\text { Concurrent } \\
\text { CRT (cisplatin/ } \\
\text { etoposide) }\end{array}$ \\
\hline
\end{tabular}

BMs, brain metastases; MRI, magnetic resonance imaging; CE-CT, contrast enhanced-computer tomography; WHO PS, World Health Organisation performance status; F, female; M, male; T, tumour; N, node; KRAS, Kirsten Rat Sarcoma viral antigen; dCE-CT, dedicated contrast enhanced-computed tomography; CRT, chemoradiation.

which patients will develop BM. In two studies $(\mathrm{N}=317$ and $\mathrm{N}=527)$, single nucleotide polymorphisms in the PI3K-PTEN-AKT-mTOR pathway and microRNAs, respectively, were associated with the development of BMs in the follow-up $[35,36]$. However, serum tumour markers such as CEA, CYFRA21-1 and CA-125 were not associated with the development of BMs [37]. Future studies with larger samples are necessary to validate these findings.

Table 3

Treatment characteristics of patients with a minimum follow-up of 1 year.

\begin{tabular}{|c|c|}
\hline \multirow[t]{2}{*}{ Treatment characteristics } & \multirow{2}{*}{$\frac{\text { Group 1 }}{\mathrm{N}=118}$} \\
\hline & \\
\hline \multicolumn{2}{|l|}{ Treatment modality, N (\%) } \\
\hline Concurrent CRT & $75(61.9)$ \\
\hline Sequential CRT & $26(22)$ \\
\hline Radical radiotherapy alone & $2(1.7)$ \\
\hline Palliative chemotherapy $^{a}$ & $2(1.7)$ \\
\hline Surgery $^{\mathrm{b}}$ & $9(7.6)$ \\
\hline $\mathrm{BSC}^{\mathrm{a}}$ & $4(3.4)$ \\
\hline \multicolumn{2}{|l|}{$\begin{array}{l}\text { Radical treatment completed }{ }^{\mathrm{c}} \text {, } \\
\quad \text { N }(\%)\end{array}$} \\
\hline Yes & $92(82.1)$ \\
\hline No & $20(17.9)$ \\
\hline \multicolumn{2}{|l|}{$\begin{array}{l}\text { Cycles chemotherapy when } \\
\text { treated with CRT, N (\%) }\end{array}$} \\
\hline 1 & $9(8.9)$ \\
\hline 2 & $6(5.9)$ \\
\hline 3 & $82(81.2)$ \\
\hline 4 & $4(4)$ \\
\hline \multicolumn{2}{|l|}{ Dose radiotherapy (Gy) } \\
\hline Mean \pm SD & $66 \pm 15$ \\
\hline $\begin{array}{l}\text { CRT, chemoradiotherapy; B } \\
\text { a Radical treatment planne } \\
\text { riorating physical condition. } \\
\text { b As part of multimodality }\end{array}$ & didly dete- \\
\hline
\end{tabular}

Prophylactic cranial irradiation (PCI) to prevent the development of symptomatic BM is also an option. The randomised phase III NVALT11/DLCROG-02 study already mentioned above showed that PCI significantly decreases the proportion of patients developing symptomatic BM at 2 years after completion of chemoradiation $(7.0 \%$ versus $27.2 \%)$, but at the cost of an increase in low-grade toxicity and without an improvement in overall survival [32].

Finally, immunotherapy could also have a role in reducing the incidence of $\mathrm{BM}$ after radical treatment, as shown in the randomised phase III PACIFIC trial (NCT02125461), evaluating adjuvant durvalumab (programmed death ligand 1 antibody) versus placebo in stage III NSCLC treated with concurrent chemoradiation. After a median follow-up of 25.6 months (from randomisation after completion of chemoradiation), the percentage of patients that developed $\mathrm{BM}$ was lower for durvalumab than for placebo $(6.3 \%$ versus $11.8 \%$ ) [38]. However, the percentage of BMs found is surprisingly low in this trial, as even the $11.8 \%$ in the placebo arm is approximately half of the percentage found in the comparator arm of contemporary stage III NSCLC PCI trials with baseline brain imaging (reviewed by Witlox et al.) [39]. Furthermore, in the PACIFIC trial baseline brain imaging was not mandatory, which should have resulted in a higher percentage of BM diagnosis during follow-up, as asymptomatic BM at baseline could have become symptomatic.

A possible limitation of our trial is the short followup, making comparison with other trials with longer follow-up difficult. However, our primary aim was to compare baseline dCE-CT and MRI brain, and one of our secondary aims was the percentage of patients with BM within a year of a negative brain MRI. Both these end-points are not influenced by the short follow-up. 
Table 4

Patient characteristics of eight patients who developed BM within a year after negative baseline MRI.

\begin{tabular}{|c|c|c|c|c|c|c|c|c|}
\hline $\begin{array}{l}\text { Patient } \\
\text { characteristic }\end{array}$ & Patient 1 & Patient 2 & Patient 3 & Patient 4 & Patient 5 & Patient 6 & Patient 7 & Patient 8 \\
\hline Gender (M/F) & $\mathrm{M}$ & $\mathrm{F}$ & $\mathrm{F}$ & M & $\mathrm{M}$ & $\mathrm{F}$ & $\mathrm{M}$ & $\mathrm{F}$ \\
\hline Age (years) & 67 & 57 & 51 & 69 & 70 & 60 & 74 & 70 \\
\hline WHO PS score & 3 & 1 & 0 & 1 & 0 & 2 & 1 & 1 \\
\hline cTstage & $\mathrm{T} 2 \mathrm{a}$ & $\mathrm{T} 1 \mathrm{~b}$ & $\mathrm{~T} 2 \mathrm{a}$ & $\mathrm{T} 3$ & $\mathrm{~T} 2 \mathrm{a}$ & $\mathrm{T} 4$ & T3 & $\mathrm{T} 2 \mathrm{~b}$ \\
\hline cNstage & $\mathrm{N} 2$ & $\mathrm{~N} 2$ & $\mathrm{~N} 3$ & $\mathrm{~N} 2$ & $\mathrm{~N} 2$ & $\mathrm{~N} 2$ & N3 & $\mathrm{N} 2$ \\
\hline $\begin{array}{l}\text { TNM stage } \\
\text { (7th edition) }\end{array}$ & IIIA & IIIA & IIIB & IIIA & IIIa & IIIB & IIIa & IIIA \\
\hline Histology & $\begin{array}{l}\text { Adeno } \\
\text { carcinoma }\end{array}$ & $\begin{array}{l}\text { Adeno } \\
\text { carcinoma }\end{array}$ & $\begin{array}{l}\text { Adeno } \\
\text { carcinoma }\end{array}$ & $\begin{array}{l}\text { Adeno } \\
\text { carcinoma }\end{array}$ & $\begin{array}{l}\text { Adeno } \\
\text { carcinoma }\end{array}$ & $\begin{array}{l}\text { Squamous } \\
\text { cell carcinoma }\end{array}$ & NOS & $\begin{array}{l}\text { Adeno } \\
\text { carcinoma }\end{array}$ \\
\hline $\begin{array}{l}\text { Molecular } \\
\text { analysis }\end{array}$ & None & None & KRAS & KRAS & KRAS & KRAS & None & None \\
\hline $\begin{array}{l}\text { Treatment } \\
\text { for stage } \\
\text { III NSCLC }\end{array}$ & $\begin{array}{l}\text { Radical } \\
\text { RTx } \\
(66 \mathrm{~Gy})\end{array}$ & $\begin{array}{l}\text { Concurrent } \\
\text { chemoradiation } \\
\text { (carbo/eto) }\end{array}$ & $\begin{array}{l}\text { Concurrent } \\
\text { chemoradiation } \\
\text { (cis/eto) }\end{array}$ & $\begin{array}{l}\text { Concurrent } \\
\text { chemoradiation } \\
\text { (cis/eto) }\end{array}$ & $\begin{array}{l}\text { Concurrent } \\
\text { chemoradiation } \\
\text { (cis/eto) }\end{array}$ & $\begin{array}{l}\text { Concurrent } \\
\text { chemoradiation } \\
\text { (cis/eto) }\end{array}$ & $\begin{array}{l}\text { Concurrent } \\
\text { chemoradiation } \\
\text { (cis/eto) }\end{array}$ & $\begin{array}{l}\text { Sequential } \\
\text { chemoradiation } \\
\text { (cis/eto) }\end{array}$ \\
\hline $\begin{array}{l}\text { Also } \\
\text { extracranial } \\
\text { progression }\end{array}$ & No & No & Yes & No & Yes & Yes & Yes & Yes \\
\hline
\end{tabular}

M, male; F, female; WHO PS, World Health Organisation performance status; c, clinical; T, tumour; N, node; M, metastases; KRAS, Kirsten Rat Sarcoma viral antigen; RTx, radiotherapy; Gy, Gray; carbo, carboplatin; eto, etoposide; cis, cisplatin; NOS, not otherwise specified.

The large proportion of patients excluded, because suboptimal brain CTs, make extrapolation to patients not screened with a dCE-CT difficult. However, we think it is also a strong point of our study that all included patients underwent the same, dedicated brain CT, and even with this dedicated CT-protocol, MRI detects asymptomatic BMs in more patients.

In conclusion, screening for BM is mandatory in the work-up of stage III NSCLC patients, and MRI is superior to a dedicated brain CE-CT. As the brain is a common site of relapse, prediction of BM development and prevention of $\mathrm{BM}$ should be the focus of clinical trials.

\section{Conflict of interest statement}

J.S. has none related to current manuscript; outside of current manuscript, J.S. received travel reimbursement from Roche.

D.D.R. has none related to current manuscript, and outside of current manuscript, D.D.R. is a member of advisory board of Bristol-Myers-Squibb, Astra Zeneca, Roche/Genentech, Merck/Pfizer and Celgene. Research grants have been received from Bristol-Myers Squibb and Boehringer Ingelheim. All income from the advisory board and from the research grants went integrally to the institution.

A.M.D. has none related to current manuscript, and outside of current manuscript, A.M.D. is member of advisory board of BMS, MSD and Roche.

L.H. has none related to current manuscript, and outside of current manuscript, L.H. received research funding from Roche and Boehringer Ingelheim (both institution) and is in advisory board of Boehringer and BMS (both institution, BMS also self) and received travel reimbursement from Roche, BMS (self), took part mentorship program with key opinion leaders funded by AstraZeneca and received fees for educational webinars: Quadia (self). All other authors have none to declare.

\section{Funding}

This research did not receive any specific grant from funding agencies in the public, commercial, or not-forprofit sectors.

\section{Acknowledgements}

None.

\section{Appendix A. Supplementary data}

Supplementary data to this article can be found online at https://doi.org/10.1016/j.ejca.2019.04.017.

\section{References}

[1] Hochstenbag MM, Twijnstra A, Hofman P, Wouters EF, ten Velde GP. MR-imaging of the brain of neurologic asymptomatic patients with large cell or adenocarcinoma of the lung. Does it influence prognosis and treatment? Lung Canc 2003;42:189-93.

[2] Moro-Sibilot D, Smit E, de Castro Carpeno J, LesniewskiKmak K, Aerts JG, Villatoro R, et al. Non-small cell lung cancer patients with brain metastases treated with first-line platinumdoublet chemotherapy: analysis from the European FRAME study. Lung Canc 2015;90:427-32.

[3] VIKC. Dutch guideline on non-small cell lung cancer. 2011.

[4] Postmus PE, Kerr KM, Oudkerk M, Senan S, Waller DA, Vansteenkiste J, et al. Early and locally advanced non-small-cell lung cancer (NSCLC): ESMO Clinical Practice Guidelines for diagnosis, treatment and follow-up. Ann Oncol : Off J Eur Soc Med Oncol ESMO 2017;28:iv1-21. 
[5] NCCN Guideline version 4.2018 Non small cell lung cancer. 2018. Version 4.

[6] NICE Clinical Guidelines Team. Lung cancer: diagnosis and management (update); Evidence reviews for the clinical and costeffectiveness of routine MRI or CT of the brain in the management of people with lung cancer prior to therapy with curative. https://www.nice.org.uk/guidance/gid-ng10061/documents/ evidence-review-2 intent. [Accessed 28 March 2019]. published online october 2018, expected final publication date.

[7] Hudson BJ, Crawford MB, Curtin JJ. Brain imaging in lung cancer patients without symptoms of brain metastases: a national survey of current practice in England. Clin Radiol 2015;70:610-3.

[8] Levy A, Faivre-Finn C, Hasan B, De Maio E, Berghoff AS, Girard N, et al. Diversity of brain metastases screening and management in non-small cell lung cancer in Europe: results of the European organisation for research and treatment of cancer lung cancer group survey. Eur J Cancer 2018;93:37-46.

[9] NICE clinical guideline 121: the diagnosis and treatment of lung cancer. 2011. 103-104.

[10] Boellaard R, Oyen WJ, Hoekstra CJ, Hoekstra OS, Visser EP, Willemsen AT, et al. The Netherlands protocol for standardisation and quantification of FDG whole body PET studies in multi-centre trials. Eur J Nucl Med Mol Imaging 2008;35: 2320-33.

[11] Kitajima K, Nakamoto Y, Okizuka H, Onishi Y, Senda M, Suganuma N, et al. Accuracy of whole-body FDG-PET/CT for detecting brain metastases from non-central nervous system tumors. Ann Nucl Med 2008;22:595-602.

[12] Ohno Y, Koyama H, Nogami M, Takenaka D, Yoshikawa T, Yoshimura M, et al. Whole-body MR imaging vs. FDG-PET: comparison of accuracy of M-stage diagnosis for lung cancer patients. J Magn Reson Imaging : JMRI. 2007;26:498-509.

[13] Lee HY, Lee KS, Kim BT, Cho YS, Lee EJ, Yi CA, et al. Diagnostic efficacy of PET/CT plus brain MR imaging for detection of extrathoracic metastases in patients with lung adenocarcinoma. J Korean Med Sci 2009;24:1132-8.

[14] Rohren EM, Provenzale JM, Barboriak DP, Coleman RE. Screening for cerebral metastases with FDG PET in patients undergoing whole-body staging of non-central nervous system malignancy. Radiology 2003;226:181-7.

[15] Hendriks LE, Bootsma GP, de Ruysscher DK, Scheppers NA, Hofman PA, Brans BT, et al. Screening for brain metastases in patients with stage III non-small cell lung cancer: is there additive value of magnetic resonance imaging above a contrast-enhanced computed tomography of the brain? Lung Canc 2013;80:293-7.

[16] Kruger S, Mottaghy FM, Buck AK, Maschke S, Kley H, Frechen D, et al. Brain metastasis in lung cancer. Comparison of cerebral MRI and 18F-FDG-PET/CT for diagnosis in the initial staging. Nuklearmedizin Nucl Med 2011;50:101-6.

[17] Seute T, Leffers P, ten Velde GP, Twijnstra A. Detection of brain metastases from small cell lung cancer: consequences of changing imaging techniques (CT versus MRI). Cancer 2008; 112:1827-34.

[18] Suzuki K, Yamamoto M, Hasegawa Y, Ando M, Shima K, Sako C, et al. Magnetic resonance imaging and computed tomography in the diagnoses of brain metastases of lung cancer. Lung Canc 2004;46:357-60.

[19] Yokoi K, Kamiya N, Matsuguma H, Machida S, Hirose T, Mori K, et al. Detection of brain metastasis in potentially operable non-small cell lung cancer: a comparison of CT and MRI. Chest 1999;115:714-9.

[20] Davis PC, Hudgins PA, Peterman SB, Hoffman Jr JC. Diagnosis of cerebral metastases: double-dose delayed CT vs contrastenhanced MR imaging. AJNR Am J Neuroradiol 1991;12: 293-300.

[21] Hendriks LE, Brouns AJ, Amini M, Uyterlinde W, Wijsman R, Bussink J, et al. Development of symptomatic brain metastases after chemoradiotherapy for stage III non-small cell lung cancer: does the type of chemotherapy regimen matter? Lung Canc 2016; 101:68-75.

[22] Soncos. Soncos Normeringsrapport 2018;6:26.

[23] Govaert SL, Troost EG, Schuurbiers OC, de Geus-Oei LF, Termeer A, Span PN, et al. Treatment outcome and toxicity of intensity-modulated (chemo) radiotherapy in stage III non-small cell lung cancer patients. Radiat Oncol 2012;7:150.

[24] Topkan E, Parlak C, Selek U. Impact of weight change during the course of concurrent chemoradiation therapy on outcomes in stage IIIB non-small cell lung cancer patients: retrospective analysis of 425 patients. Int J Radiat Oncol Biol Phys 2013;87: 697-704.

[25] Pless M, Stupp R, Ris HB, Stahel RA, Weder W, Thierstein S, et al. Induction chemoradiation in stage IIIA/N2 non-small-cell lung cancer: a phase 3 randomised trial. Lancet 2015;386: $1049-56$.

[26] Eberhardt WE, Pottgen C, Gauler TC, Friedel G, Veit S, Heinrich V, et al. Phase III study of surgery versus definitive concurrent chemoradiotherapy boost in patients with resectable stage IIIA(N2) and selected IIIB non-small-cell lung cancer after induction chemotherapy and concurrent chemoradiotherapy (ESPATUE). J Clin Oncol : Off J Am Soc Clin Oncol 2015;33: 4194-201.

[27] Senan S, Brade A, Wang LH, Vansteenkiste J, Dakhil S, Biesma B, et al. PROCLAIM: randomized phase III trial of pemetrexed-cisplatin or etoposide-cisplatin plus thoracic radiation therapy followed by consolidation chemotherapy in locally advanced nonsquamous non-small-cell lung cancer. J Clin Oncol : Off J Am Soc Clin Oncol 2016;34:953-62.

[28] Reck M, Popat S, Reinmuth N, De Ruysscher D, Kerr KM, Peters S. Metastatic non-small-cell lung cancer (NSCLC): ESMO Clinical Practice Guidelines for diagnosis, treatment and followup. Ann Oncol : off J Eur Soc Med Oncol ESMO 2014;25(Suppl 3):iii27-39.

[29] Tournoy KG, Van Meerbeeck JP. Lung cancer staging: imagine fewer images. Eur Respir J 2018;52.

[30] Vollmer I, Sanchez M, Rami-Porta R. Lung cancer staging: imagine fewer images. Eur Respir J 2018;52.

[31] Gaspar LE, Chansky K, Albain KS, Vallieres E, Rusch V, Crowley JJ, et al. Time from treatment to subsequent diagnosis of brain metastases in stage III non-small-cell lung cancer: a retrospective review by the Southwest Oncology Group. J Clin Oncol : Off J Am Soc Clin Oncol 2005;23:2955-61.

[32] De Ruysscher D, Dingemans AC, Praag J, Belderbos J, TissingTan C, Herder J, et al. Prophylactic cranial irradiation versus observation in radically treated stage III non-small-cell lung cancer: a randomized phase III NVALT-11/DLCRG-02 study. J Clin Oncol : Off J Am Soc Clin Oncol 2018;36:2366-77.

[33] Sze G, Johnson C, Kawamura Y, Goldberg SN, Lange R, Friedland RJ, et al. Comparison of single- and triple-dose contrast material in the MR screening of brain metastases. AJNR Am J Neuroradiol 1998;19:821-8.

[34] Yuh WT, Tali ET, Nguyen HD, Simonson TM, Mayr NA, Fisher DJ. The effect of contrast dose, imaging time, and lesion size in the MR detection of intracerebral metastasis. AJNR Am J Neuroradiol 1995; 16:373-80.

[35] Li Q, Yang J, Yu Q, Wu H, Liu B, Xiong H, et al. Associations between single-nucleotide polymorphisms in the PI3K-PTENAKT-mTOR pathway and increased risk of brain metastasis in patients with non-small cell lung cancer. Clin Cancer Res : Off J Am Assoc Canc Res 2013;19:6252-60.

[36] Lu Y, Govindan R, Wang L, Liu PY, Goodgame B, Wen W, et al. MicroRNA profiling and prediction of recurrence/relapse-free survival in stage I lung cancer. Carcinogenesis 2012;33:1046-54.

[37] Cedres S, Nunez I, Longo M, Martinez P, Checa E, Torrejon D, et al. Serum tumor markers CEA, CYFRA21-1, and CA-125 are 
associated with worse prognosis in advanced non-small-cell lung cancer (NSCLC). Clin Lung Cancer 2011;12:172-9.

[38] Antonia SJ, Villegas A, Daniel D, Vicente D, Murakami S, Hui R, et al. Overall survival with durvalumab after chemoradiotherapy in stage III NSCLC. N Engl J Med 2018;379(24): $2342-50$.
[39] Witlox WJA, Ramaekers BLT, Zindler JD, Eekers DBP, van Loon JGM, Hendriks LEL, et al. The prevention of brain metastases in non-small cell lung cancer by prophylactic cranial irradiation. Front Oncol 2018:8:241. 